\title{
Perceptions of EFL and non-EFL teachers about EFL teacher's code switching
}

\author{
Cynthia Alexandra Miranda Chacón \\ Escuela de Literatura y Ciencias del Lenguaje \\ Universidad Nacional, Costa Rica \\ Natalia Sofía Murillo Pereira \\ Escuela de Literatura y Ciencias del Lenguaje \\ Universidad Nacional, Costa Rica \\ José David Rodríguez Chaves \\ Escuela de Literatura y Ciencias del Lenguaje \\ Universidad Nacional, Costa Rica
}

\begin{abstract}
Resumen
El presente artículo explora el tema y el uso del "code switching", o mezcla de idiomas, dado entre los docentes de inglés como lengua extranjera (ILE). Dicho artículo pretende comprender las percepciones de los docentes de ILE y de aquellos docentes cuya disciplina o área de trabajo es distinta al inglés hacia el uso del "code switching" por parte de la primera población. Estos profesores, de dos colegios de la provincia de Heredia, brindan información que demuestra similitudes acerca de la práctica, tipos, usos y contextos del "code switching". No obstante, se destaca que mientras los docentes de inglés defienden que la mezcla de idiomas se da de manera natural e inconsciente, los docentes de otras áreas claman que los docentes de ILE están lo suficientemente conscientes para saber con quién, cómo, cuándo y dónde hacer uso de mezcla de idiomas. Este estudio explora las distintas percepciones y actitudes lingüísticas de ambas poblaciones acerca de dicho fenómeno.
\end{abstract}

Palabras claves: mezcla de idiomas, percepciones, actitudes lingüísticas, docentes de ILE 


\begin{abstract}
The following article addresses the topic of code switching among English as a foreign language (EFL) teachers. This article aims to understand the perceptions EFL teachers and non-EFL teachers have toward the first group's usage of code switching. Though some similarities about code switching practices were found in both groups, EFL and non-EFL teachers disagree with the functions of code switching and its usage in general. These teachers, from two high schools located in the province of Heredia, provided data which proves similarities about the practice, types and contexts for code switching. Nonetheless, it is noticeable that whereas EFL teachers advocate their language mixing as natural and unconscious, non-EFL teachers claim that EFL teachers are aware enough to know whom, how, when and where to code-switch. This study explores both groups' perceptions and linguistic attitudes toward such phenomenon.
\end{abstract}

Key words: code switching, perceptions, linguistic attitudes, EFL teachers

\section{Introduction}

$\mathrm{T}$ he existence of code switching in teachers of foreign languages is common. In many high schools in Costa Rica, it is customary to hear EFL teachers easily shifting from English to Spanish in the same sentence or within the same conversation. Indeed, code switching is practiced by most speakers who are in a bilingual context just like EFL teachers in Costa Rica. Among this population, the usage of code switching is seen as a natural way of expressing opinions and communicating information to their peers; however, many nonEFL teachers may not feel comfortable or may not agree with EFL teachers code switching when interacting in an expected Spanish speaking setting. For instance, while taking part of a conversation in the teachers' lounge or in a teachers' meeting or sharing casually with co-workers, code switching may cause wrong conceptions about the factual usage of the codes (i.e. English and Spanish) used by EFL teachers.
Anderson (2006) refers to code switching in different contexts such as language fluency and literature where he differentiates two types of code switching: grammatical and ungrammatical. According to Anderson's hypothesis grammatical code switching will be more positively viewed than ungrammatical code switching; nonetheless, his results demonstrate that although highly proficient bilinguals approve code switching, they fail to distinguish the difference from both types of code switching in context. Weston (2012) approached the code switching patterns native Gibraltarians do to English within four generations; the first one from 14 to 25 years old, the second people from 26 to 39 years old, the third generation enclosed people ages 40 to 59 and the fourth one includes people over 60 years old. According to Weston's results, in code switching variation in Gibraltar, the younger generations demonstrate greater code switching patterns than the older ones. This study mainly deals with what Anderson and Toribi (2007) defined as language attitudes: "the way in which 
observers react toward language varieties and language use" (p.8).

The aim of this research study is, then, to address non-EFL teachers' perceptions as well as EFL teachers' perceptions toward this phenomenon in order to have a clear idea of the attitudes involved, and to contrast both groups' perspectives about code switching. Therefore, this study defines code switching, its context and functions, and it identifies the perceptions of both populations toward the topic. Both EFL and non-EFL teachers' perceptions will be contrasted in order to have a better understanding of the phenomenon. Teachers participating in the study work in two high schools where an emphasis on English instruction takes place and EFL teachers are expected to use English in all contexts, so the usage of code switching by EFL teachers is more likely to occur, arising reactions from non-EFL teachers.

In the field of linguistics, specifically related to bilingualism, there are many theories which prevent and others which enhance the usage of code switching in bilinguals; however, from this process substrate some attitudes that can be the core of those perceptions. The importance of those attitudes toward code switching at the same time contrasts how those attitudes can change between EFL and non-EFL teachers.

\section{Theoretical Framework}

Many bilingual, or even multilingual, speakers can choose which language (code) to use depending on the context they are immersed in. Nonetheless, being fluent in several languages may cause the mind to find it easy to switch from one code to the other, mixing them and, therefore, creating another code. In this sense, EFL teachers in Costa Rica are not exempt from performing code switching within different contexts. In fact, Anderson (2006) claimed that "code switching, or the alternation between two languages, is a common outcome of living in a multilingual setting, so that it is found in diverse settings, from the mundane (e.g. playground, workplace) to the sublime (e.g. poetry, novels)" (p. 1).

\section{Intrasentential and intersentential code switching}

Draemel (2011) defined and exemplified Spanish-English code switching "como la habilidad bilingüe (as the bilingual ability) to alternate effortlessly desde un idioma al otro (from one language to another), either at clause boundaries $o$ dentro de la misma oración (or within the same clause)" (p. 1). Whereas the type of code switching can be determined by the level of proficiency of the speakers and the level of consciousness, the context can be a determinant factor for mixing languages. Lipski (2005) indicated that this shift is very common among Hispanic communities in the United States, where bilinguals mainly speak English and borrow expressions from Spanish, which turns into intra-sententional code switching. On the contrary, since Spanish is the predominant language in Costa Rica, bilingual speakers would be expected to use this language and occasionally 
borrow phrases and words from English. If the selection of codes is based taking into account discourse context and interlocutors, then inter-sententional code switching may occur.

\section{Grammatical and ungrammatical code switching}

Poplack (1980) pointed out two main directions within intra-sentential code switching, which are related to grammar or syntactic rules. This author enunciates two grammatical constraints in code switching: the equivalence constraint and the free morpheme constraint.
1. The Equivalent Constraint. According to this author, "code-switches will tend to occur at points in discourse where juxtaposition of L1 and L2 elements does not violate a syntactic rule of either language, i.e. at points around which the surface structures of the two languages map onto each other" (585). That is, the equivalent constraint is applied when the word order before or after the switch is homologous in both languages. See Figure 1.

\section{Figure 1. Example of equivalent word order switch. Taken from Poplack (1980).}
\begin{tabular}{l|l} 
A. & Eng \\
B. & Sp \\
C. & Cs
\end{tabular}
\begin{tabular}{c|c} 
I & told him \\
Yo) & le dije \\
I & tod him
\end{tabular} \mid
\begin{tabular}{l|l} 
that & so that \\
eso & pa' que \\
that & pa' que
\end{tabular}
he

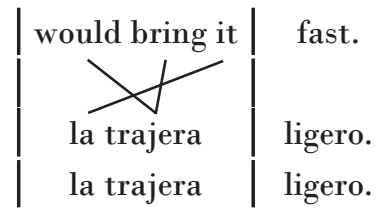

In the case above, it is seen how the word order in English does not contrast with the word order switch made to Spanish. Poplack affirms that Spanish-English bilinguals undertake code switching by preferring switches before or after a tag like in 'You're almost done with school, verdad?' (You're almost done with school, right?); or before an adjective in the predicate such as 'Es muy cute. (It's really cute.)'; or between clauses like 'That's the lady que tiene cuatro hijos (That's the lady who has four children)' (Hammink, 2000, p. 6). An ungrammatical code switching would not take into consideration the equivalent constraint, and will, therefore, undervalue the syntactic rule of both languages by switching between a clitic and a verb or a negative and a verb. Hammink (2000) exemplified

this premise by giving two examples of ungrammatical code switching that defies the equivalent constraint: ' $E l$ niño le hit. (The boy hit him.)' or 'El jefe no want to pay us. (The boss does not want to pay us.).' (p. 6). As it is noticed in the previous examples, the switches do not follow the grammar rules of word order; however, this does not prohibit or stop bilinguals from using such types of switchings; they will only claim to perform ungrammatical code switching.

2. The Free Morpheme Constraint. "Codes may be switched after any constituent in discourse provided that constituent is not a bound morpheme," as stated by Poplack (1980, p. 586). If a morpheme can stand alone within a sentence, it can be accurately grammatically 
code-switched; nonetheless, if a morpheme can only appear as part of a larger word (in the case of affixes), its code-switch is ungrammatical. Poplack exemplifed the above by referring to two statements: 'una buena excuse' (a good excuse), which is a grammatical code-switch, and 'eatiendo' (eating) which refers to an ungrammatical code-switch given the fact that 'iendo' or 'ing' are both affixes, that is, bound morphemes. According to Gumperz and Timm, "no switches are allowed between subject pronoun and verb" (as cited in Hammink, 2000, p. 7). This is called the subject pronoun and verb constraint and an exception to the rule is given when both languages have the same gender systems which does not account for English (with one gender class) and Spanish (with two gender classes). For example, 'Yo ate the cake. (I ate the cake)' will be an ungrammatical switch. In other words, whenever there is a verb and an infinitive as in 'love to read' the code switching within that verbal phrase will be ungrammatical as in 'María ama read love novels. (María loves to read love novels.)'; this situation is called the verb and infinitive complement constraint (Hammink, 2000, p. 7).

\section{Metaphorical and situational code switching}

In addition to grammatical and ungrammatical code switching, which examines the phenomenon from a structural perspective, what researchers have called metaphorical and situational code switching are explained below, which intends to explain the phenomenon from a functional perspective. Bloom and Gumperz stated that metaphorical code switching is often used as a conversation strategy to develop or mitigate conversational acts such as requests, denials, topic shifts or clarifications (as cited in Shin, 2010, p. 95). This tendency is normal in bilingual or multilingual communities to discuss a topic that might change the conversation domain. Conversely, situational code switching is related to a change in a situation; for example, when a new person joins to a conversation, or when a change in a conversation setting or topic takes place. Metaphorical code switching is therefore labeled as 'conversational code switching'.

\section{Diglossia and code switching}

The phenomenon diglossia is defined by Ferguson "(...) as the existence of a divergent variety of language which is only used in particular situations" (as cited in Nilep, 2006, p. 5). The term diglossia is more limited to varieties of the same language with some functional division between unrelated languages; which means that it bears on the notion of situational switching. The main difference between diglossia and code switch bases on the fact that the former is more intentional when changing from one dialect to another due to a situation while the latter is perceived as a subconscious change of the language.

\section{Functions of code switching}

As explained by Fennema-Bloom (2010), code switching, seen from a pedagogic-instructional view, has been 
categorized by Guthrie into five communicative functions: 1) translation, 2) inclusion (we-code), 3) procedures and directions, 4) clarifications; and 5) checks for comprehension; this typology is merged by Fennema-Bloom with the one suggested by Merrit et al., which focuses on the functions code switching would serve for classroom instruction. Although this article does not aim at exploring the functions of code switching in instruction, the researchers have adapted some of them found in Fennema-Bloom's framework and have complemented them with an additional framework proposed by Awan and Sheeraz (2011), to determine the sociolinguistics functions by which code switching takes place in EFL teachers socially interacting among themselves or with non-EFL teachers; these are described as follow:

1. Repairing communication. Speakers who share the same native language (NL) and know or speak a foreign language (FL), in a context in which the latter is not an official language, might vary considerably in terms of mastering this FL. Consequently, they might find themselves in situations where they can repair communication breakdowns by alternating code; in other words, they would intra-sententionally use one code as a back-up when failing in finding the right expression in the target language.

2. Communicating idiosyncratically. Names of places, important historical events and characters, and other cultural elements might suffer transformations in their morphology or phonology depending on the language used. These changes might make these proper names unintelligible, so they could be pronounced or kept in the code that produces fewer misunderstandings. Furthermore, some words and phrases might not have equivalent forms in the target code; culturally complex or culture-specific ideas are expressed using another code to carry the true meaning of these ideas or to trace cultural identity through them. Even if these ideas were to be translated into the target code, speakers have the need of using the code where these words or phrases can be marked idiosyncratically.

3. Creating habitual conversation. Speakers with similar traits-aside from them sharing the same NL or FL-might alternate codes to establish rapport or closeness toward their peers (e.g. coworkers or classmates). For instance, EFL teachers as part of a bilingual speech community might develop their own dialect within such community or their own idiolect comprised by metalanguage and jargon, which can be easily understood among their colleagues as a way to demonstrate solidarity and intimacy.

4. Expressing emotions. It is generally assumed that the language speakers grow up with (i.e. NL) is the one chosen for them to express how they feel. Consequently, an EnglishSpanish bilingual speaker, whose NL is Spanish, might feel more at ease when transmitting feelings in this language rather than in English. Nonetheless, this fact depends on the context, in terms of 
EFL teachers within schools they may feel at ease to express their emotions in the FL when talking to their colleagues.

\section{Methodology}

The teacher participants belong to two high schools where an emphasis in English is part of the curriculum. The first setting is the Liceo Experimental Bilingüe de Belén (LEBB), and Colegio Santa María de Guadalupe (a.k.a. SAMAGU); in both places, English is mandatory to be spoken in class. The EFL teachers from these schools were selected since they implement syllabi in which the quality and the quantity of EFL subjects are significant, which allows them to instruct in the four different skills with major detail. This population is, therefore, more expected to use EFL within the classroom context. In addition, since the researchers are their co-workers, they know that they continue using English outside the classroom context, even if surrounded by non-EFL teachers who might or might not be proficient in English. Links to online questionnaires were e-mailed to a sample of fifty teachers from both high schools. However, only seven EFL teachers and six non-EFL teachers submitted it.

\section{Results}

\section{About participants}

EFL informants were five females and two males who have worked in EFL teaching for more than three years. The age range of the informants goes from
26 years old to 36 years old; four of them have a bachelor's degree in English Teaching, one a licenciatura degree and two of them have a master's degree, all of them related to the field of teaching. On the other hand, the six non-EFL teachers comprised three males and three females, whose age range goes from 24 years old to 37 years old.

In the case of the EFL teachers, they were first asked which language, English or Spanish, they speak more often: $57 \%$ of them expressed that they use both languages while $43 \%$ of them expressed that they use more Spanish. In such sense, none of the EFL teachers mentioned that the most spoken language was English.

\section{About code switching practices}

Informants were asked about the frequency, the context and the topics when mixing English and Spanish to obtain a general overview of the factual practice in code switching. EFL teachers pointed out that they mix these two languages with a fair degree in frequency: $14 \%$ said that they always do it; $29 \%$ stated that they do almost always do it; $43 \%$ expressed that they sometimes do it; and $14 \%$ asserted that they almost never do it. These findings match the perceptions non-EFL teachers have about the instances they have heard their EFL colleagues code-switching. They all recalled having heard the second group mixing languages: $17 \%$ mentioned that EFL teachers almost always do it; the same percentage shows that non-EFL teachers have heard EFL teachers almost never code-switch, while the largest percentage $(66 \%)$ of non-EFL teachers recorded that EFL sometimes 
mix languages. Both groups agree on the fact that EFL teachers have ever mixed languages, but non-EFL state that EFL teachers do not have this practice all the time.

About the specific moments in which EFL teachers mix languages, EFL teachers were asked to whom they code-switch along with the context they do this practice. This group claimed to mix languages within the school context and even outside school: $29 \%$ of EFL teachers said that they mix languages when talking to other EFL teachers, specifically during the English Department meetings and school general staff's meetings, 22\% reported mixing languages when running into students in a hallway; $21 \%$ said having code-switched while having a conversation with non-EFL teachers in the teachers' lounge; and 18\% said they mix languages with relatives and $10 \%$ said they do so with friends. On the other hand, non-EFL teachers expressed that most EFL teachers (56\%) mix languages if talking to other EFL teachers. According to non-EFL teachers, the remaining percentage indicates that EFL teachers do this practice with non-EFL teachers and students in a lowest degree. See Figure 2.

Figure 2. Contexts for EFL teachers' code switching reported by non-EFL teachers. Source: Questionnaire, June 2015.

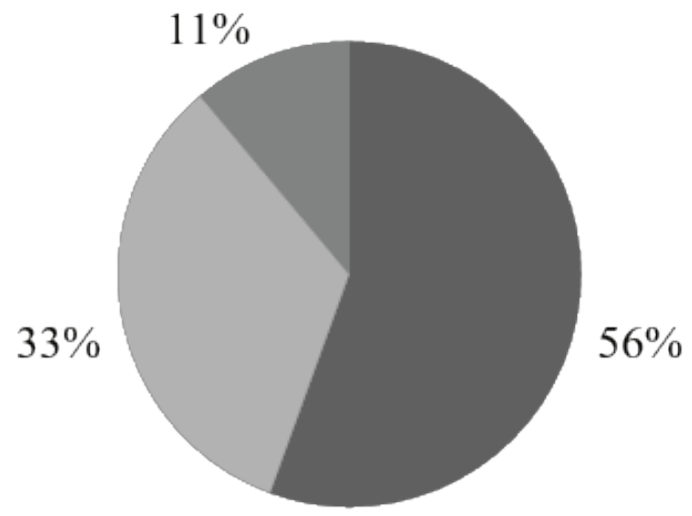

Talking to other EFL teachers Talking to nonEFL teachers Talking to students
It is noticeable that EFL teachers would mostly mix languages in contexts in which their interlocutors have background knowledge in the two languages. EFL teachers report that these interlocutors are themselves and students, while non-EFL teachers consider EFL counterparts do not only mix languages among themselves, but they also mix when talking to interlocutors who may or may not have background in English (i.e. non-EFL teachers).
When being asked about the kind of topics in which EFL teachers mix languages, both groups of informants declare similar responses. A third part of EFL teachers say that they do this practice for communicating personal matters, which is confirmed with $38 \%$ of non-EFL who state this practice is used for this topic. Moreover, leisure or entertainment is the second topic for code switching to take place, according to $33 \%$ of EFL teachers and $31 \%$ 
of non-EFL teachers. Another topic for the usage of this practice is academics; while $20 \%$ of EFL teachers express that they code-switch in this topic, $21 \%$ of non-EFL teachers report the use of this topic for code switching by EFL teachers. Finally, 14\% of EFL teachers and $8 \%$ of non-EFL teachers state that culture is a topic in which EFL teacher mix languages. See Figure 3.

Figure 3. Topics in EFL teachers' code switching. Source: Questionnaire, June 2015.

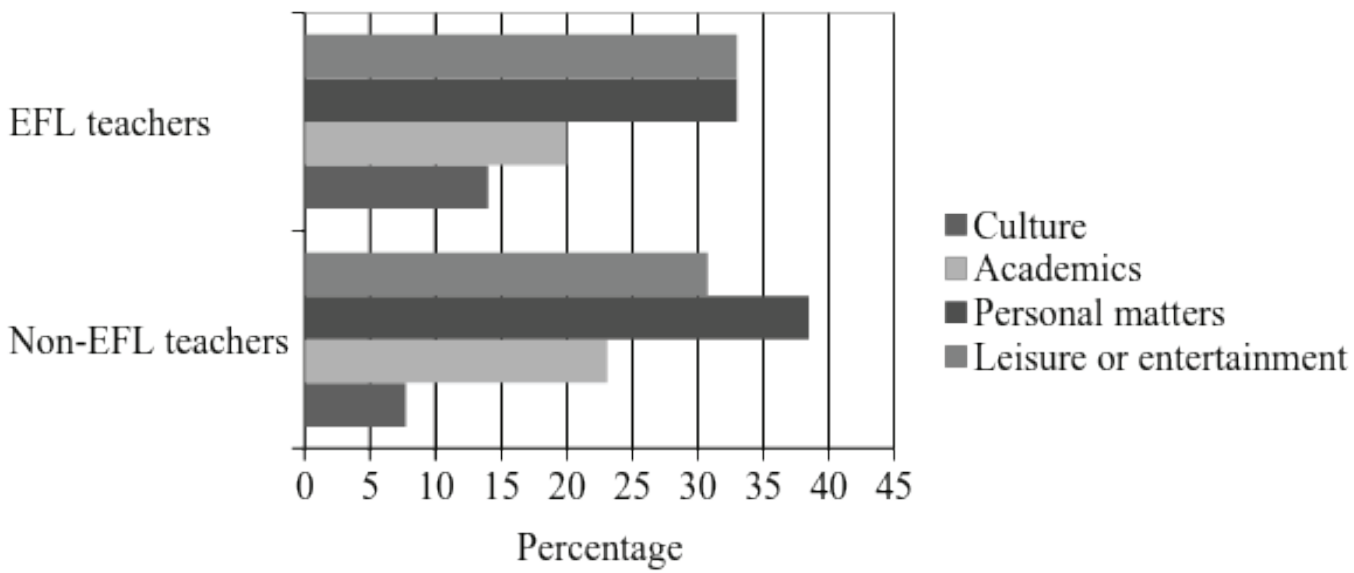

\section{About code switching functions}

Regarding the code switching functions, which refers to the reasons why EFL teachers use code switching, four major reasons were aforementioned: repairing communication (when not knowing the equivalent expression in the target language), communicating idiosyncratically (when cultural fixed phrases or words are not translated in the target language), expressing strong emotions (when speakers feel the need to change codes to express an emotion they may feel is better said in one or the other code), and creating habitual conversations (when talking to peers, coworkers or classmates). When being asked about the reasons EFL teachers mixed languages, both EFL and non-EFL teachers have contrary ideas. As seen in the figure below, the perceptions between EFL and non-EFL teachers are contradictory. While a $57 \%$ of EFL teachers affirm that they use code switching to facilitate communication, a $67 \%$ of non-EFL teachers claim that EFL teachers practice code switching to exclude someone from the conversation. Interestingly enough, other main reason that non-EFL teacher claim EFL teachers code switch, according to $33 \%$ of the informants, is to show off their linguistic skills or to be trendy. In view of these perceptions, we can allude that non-EFL teachers do not feel comfortable with code switching among EFL teachers, they can even feel offended or threatened by its usage. See Figure 4 . 
Figure 4. Reasons why EFL teachers code-switch. Source: Questionnaire, June 2015. Most of the non-EFL English teachers agree that they feel uncomfortable

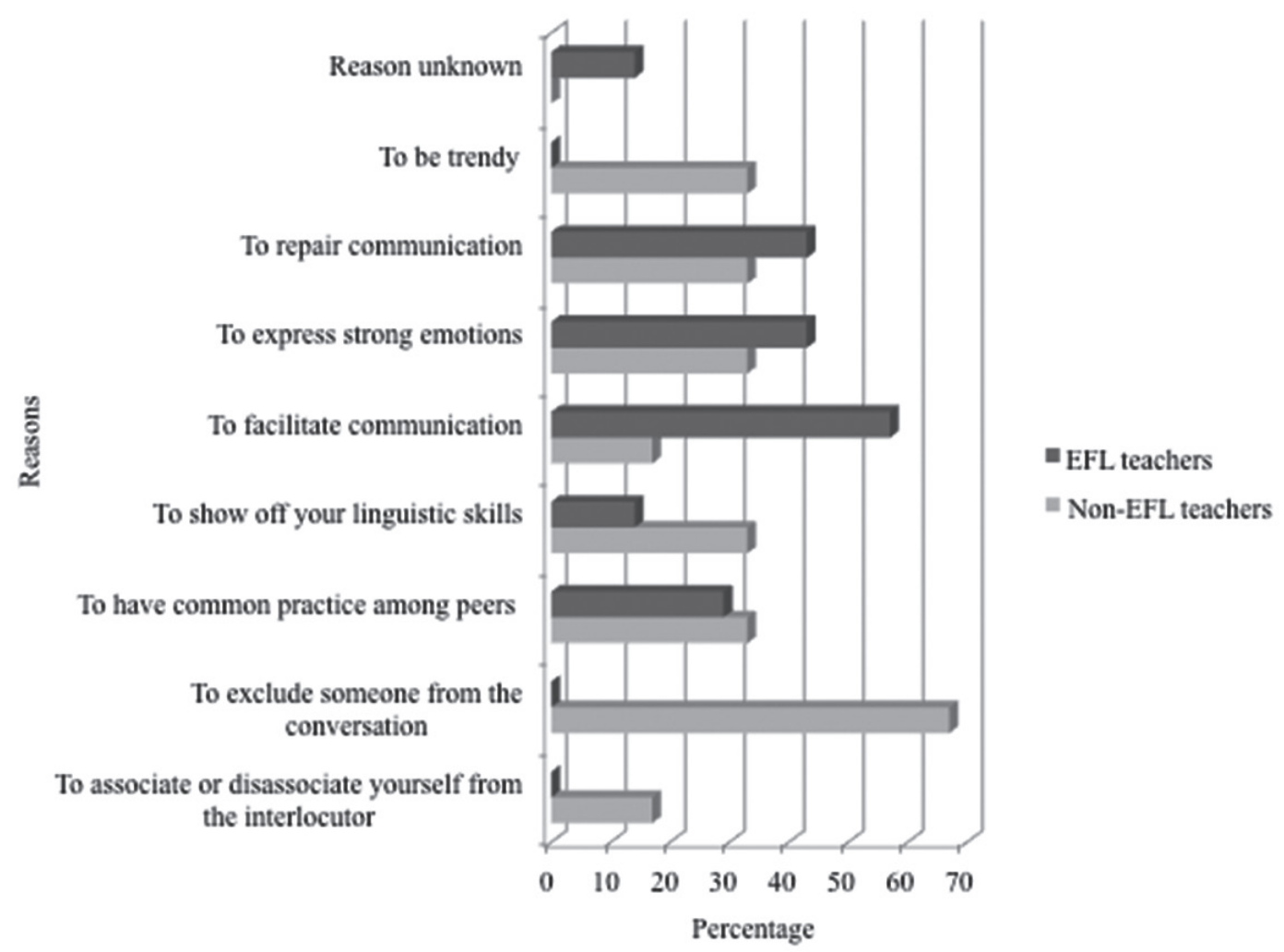

when EFL teachers code-switch. One of the informants claims that “... la mezcla de lenguas provoca el desmejoramiento de ambas lenguas." This point of view is repeated in different ways throughout most of the informants; some of them may even feel excluded or offended by the usage of code switching. For instance, one informant affirms that "...en ocasiones comentan situaciones en inglés para que las personas no entiendan sin embargo algunas personas conocemos el idioma y terminamos entendiendo el idioma." In such case, the informant feels offended and affirms that EFL teachers may use code switching to exclude someone from the conversation being held at the moment. From all the non-EFL teachers, only one informant avows there is no a problem with such practice; this informant relates such practice as a dialect calling it a type of 'patua' and featuring it as an 'espanglish' practice.

\section{About code switching types}

As mentioned in the theoretical framework, there are different types of code switching. One type is related to how EFL teachers code-switch, that is, if they mix these languages by using certain words or phrases within a sentence (intra-sententional) or by 
alternating statements from one language to the other (inter-sententional). When being asked which type of code switching EFL teachers use the most, both EFL and non-EFL teachers had different points of view. See Figure 5.

Figure 5. Ways EFL teachers mix languages. Source: Questionnaire, June 2015.

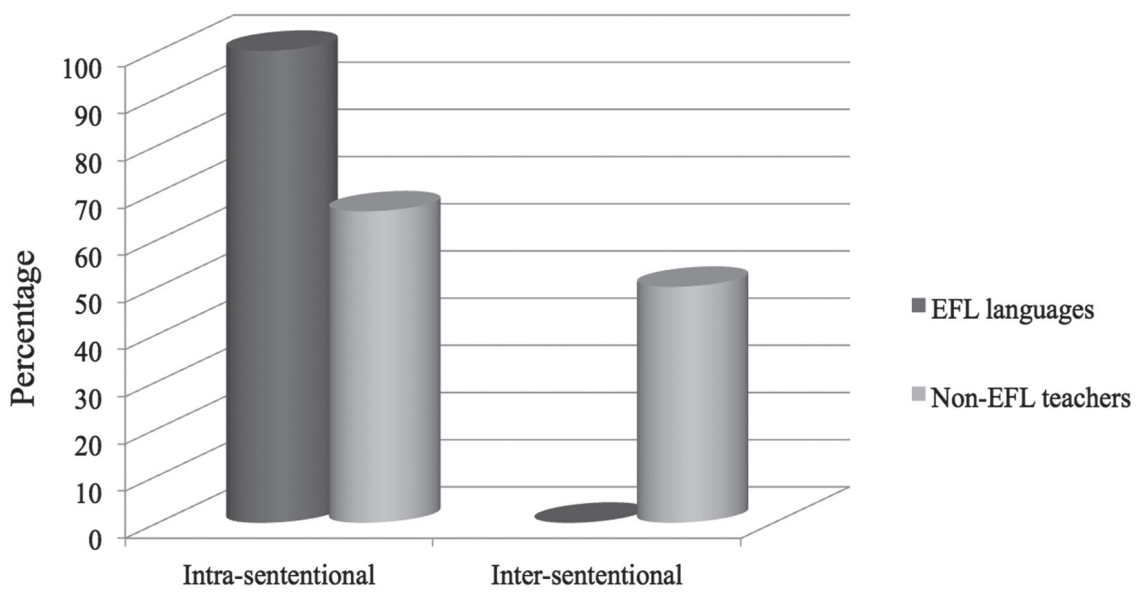

As seen in Figure 5, all of the EFL teachers allege that they use intra-sententional code switching, while nonEFL teachers avouch that although EFL teachers use more the intra-sententional type, the inter-sententional type is also practiced. Under these circumstances, it can be said that EFL teachers may use both types of code switching but are more aware ofthe using intra-sententional code switching.

When talking about grammatical and ungrammatical types of code switching, we referred strictly to the place the mix in codes occurs within a sentence; in other words, it is related to where in the sentence the code switching structure occurs. According to examples given and some other given by the EFL teachers, all of them practice grammatical code switching in a sense that the constraints mentioned in the theoretical framework were followed. Specifically, the equivalent constraint was appreciated in examples such as 'El director was mad', 'No quiero trabajar más 'cause I'm tired' and 'I cannot afford it esta muy caro' where the word order before or after the switch is homologous in both languages. Similarly, the free morpheme constraint was respected in sentences such as 'Estos alumnos me vuelven crazy', 'esta demasiado hot' and 'Esos estudiantes estaban cheating' where the code-switch was made in an unbound morpheme like 'hot', 'crazy' and 'cheating'. Additionally, the subject verb constraint was also complained in some sentences like 'Mr Principal dijo que bla bla bla...' or 'Que rico breakfast en Dennis!', or 'Me gusta esa music' where there is a relation with the subject and the verb as in 'Mr Principal dijo', 'rico breakfast', 'gusta esa music'. Finally, there were no examples provided by EFL teachers were they did not use the verb-infinitive constraint as in 'Me gusta dance' (I like to dance) where the infinitive is part of the verb code-switch. 
Overall, code switching is a frequent practice among EFL teachers and, although some non-EFL perceptions may disagree and feel uncomfortable with the practice, it does not mean that both languages are being damaged by its practice; on the contrary, bilinguals are expanding their horizons by putting in practice both cultures expressions and codes.

\section{About perceptions of non-EFL teachers}

The non-EFL teachers were asked if they considered that the EFL teachers were conscious of the language mixing at the time they speak. These are some the opinions shared:

(1) "si".

(2) "A veces especialmente cuando lo que desean es que los demás no entiendan lo que dicen".

(3) "Si, considero que ellos, de forma inferencial demuestran el gusto por usar la lengua inglesa en combinación con la española para demostrar sus conocimientos y, también para mantener en práctica su segunda lengua y ser comprendidos por hispanohablantes o, en fin, con otros interlocutores".

(4) "Podría ser que lo hagan en forma involuntaria, pero a veces algunos los hacen en forma conscientes".

(5) "si, son muy conscientes".

(6) "en ocasiones ya que la mezcla puede ser intencional”.

As these opinions demonstrate, the non-EFL teachers agree that EFL teachers are conscious about the fact that they are mixing languages; they expressed that on some occasions it could be an involuntary action although they do it in an intentional way and very conscious about it, especially if they do not want to be understood by other people.

Moreover, non-EFL teachers asked if they consider EFL teachers' code switching as a correct practice. In relation to this question, these informants expressed the following:

(1) "Creo que si yo fuera profesor de Inglés, hablara constantemente en Inglés".

(2) "Considero que no es lo más apropiado".

(3) "No es correcto porque, desde mi perspectiva, el español como lengua, y por ende, entidad viva y evolutiva puede violentar con anglicismos incorporados de forma viciosa o antojadiza, al mezclar los dos idiomas".

(4) "No, la lengua se debe usar en mayor expresión, se esté en español o inglés"

(5) "no, debe mantenerse uno solo".

(6) "Cuando no recuerdan una palabra si eso demuestra dominio pero cuando es para usar alguna expresión o comentarios 'confidenciales' no".

In most of the cases, non-EFL teachers demonstrated that this practice is not correct; according to them, it is not appropriate especially if this mixing is used to express only confidential messages; also, they expressed that each language, being Spanish or English itself, must be fully used but in their individual context. 


\section{Analysis}

At the beginning of the study, EFL participants assure that English was not their mostly used language when communicating outside the classroom. Nonetheless, once interviewed, about an $86 \%$ of the EFL teachers researched agreed that they switch codes sometimes, often or always; that is, only a $14 \%$ agree that code switching was almost never used, which was related to the perceptions of non-EFL teachers. These results denote a frequency of code switching in EFL teachers that may be done subconsciously, given the fact that they negate doing so at the beginning. However, after the research carried on, results clearly noted their codeswitching remarking that it is perceived as a subconscious change of the language.

Additionally, the fact that $51 \% \mathrm{EFL}$ teachers state that they mix languages when talking to other EFL teachers, during the English Department meetings, school general staff's meetings, or when running into students in a hallway represents that EFL teachers mostly used codeswitching with the function of creating habitual conversation where they alternate codes to create a relationship or closeness in this case toward their peers or students because they have knowledge of the language as well. Moreover, the research showed that EFL teachers also codeswitch with the function of communicating emotions; that is, to expressing feelings about personal topics, given that both EFL and non-EFL teachers agree that one of the topics more likely to codeswitch is when talking about personal matters.

Furthermore, EFL teacher perceived their code switching more intra-sententionally than inter-sententionally; however, non-EFL teachers claim EFL teachers portray both types of switching. This fact emphasizes the subconscious part of code switching. Nonetheless, non-EFL teachers disagree with this claim and assure that EFL teachers are conscious about their code switching as shown in many of their opinions.

Finally, EFL teachers and nonEFL teachers' perceptions disagree on whether the functions for using codeswitching may seem "reasonable", "exclusive", or "arrogant". Indeed, 57\% of the EFL teachers agree they code switch to facilitate communication while $67 \%$ of non-EFL teachers perceive code switching as a form of exclusion from a conversation, showing off their fluency or to be fashionable. These statements show how uncomfortable some non-EFL teachers feel when EFL teacher code switch.

\section{Conclusions}

EFL teachers and non-EFL teachers agree that code switching is a common practice among EFL teachers. The constant use of both English in the classroom context may be a cause for the frequent practice of this phenomenon even outside the classroom walls. The most common addresses when code switching are EFL colleagues and students, and the most common topics for its practice are personal matters and entertainment. EFL teachers code switch for many reasons being 'creating habitual conversations' and 'expressing feelings' the functions most likely to be used with code switching; however, this does not mean that other functions are not to be used. In the same sense, both inter-sententionally and intra-sententionally code 
switching is applied by EFL teachers. EFL teachers' perceptions about code switching are usually positively-connotated like facilitating information or repairing communication. However, non-EFL teachers' perceptions address code switching with a negative connotation as this group think its practice is threatening the languages per se and that its usage is related to gossiping or excluding someone from a conversation. For these reasons, non-EFL teachers disagree with code switching and alert EFL teachers to use only one language, the one specifically related to the culture they are immersed in. In this matter, Wardhaugh (1976) clarified,

Monolingualism (...) is such a widely accepted norm in so many parts of the Western world that it is often assumed to be a worldwide phenomenon, to the extent that bilingual and multilingual individuals may appear to be 'unusual.' Indeed, we often have mixed feelings when we discover that someone we meet is fluent in several languages: perhaps a mixture of admiration and envy but also, occasionally, a feeling of superiority in that many such people are not 'native' to the culture in which we function. (p. 96)

Indeed, code switching, from a nonEFL teachers' perspective, may have a negative connotation of not being true to your culture; however, EFL teachers disagree with such connotation and believe that code switching is a common practice due to the constant use of both languages and it does not affect their cultural roots. In fact, EFL teachers and non-EFL teacher perceptions about the usage approval, correctness and accuracy of code switching greatly contradict each other when EFL teachers claim it eases communication and create rapport while non-EFL teachers feel exclude, perceive arrogance and claim it is not a proper use of both languages. Finally, both EFl and non-EFL teachers should grasp code switching not as a 'malpraxis' of Spanish or English but as a tool EFL speakers have for being understood and broaden their worldview. All in all, an Austrian philosopher called Ludwig Wittgenstein claimed that "If we spoke a different language, we would perceive a somewhat different world".

\section{Note}

1. "Inspiring quotes about language and multilingualism" (n. d.). Retrieved from http://www.thepiripirilexicon. com/2013/02/inspiring-quotes-aboutlanguage-and.html

\section{Bibliography}

Anderson, T. K. (2006). SpanishEnglish Bilinguals' Attitudes Toward Code switching: Proficiency, Grammaticality and Familiarity (Doctoral dissertation). Retrieved from https://etda.libraries.psu. edu/catalog/7076

Anderson, T. K., \& Toribio, A. J. (2007). Attitudes towards lexical borrowing and intra-sentential code switching among Spanish-English bilinguals. Spanish in Context 4(2), 217-240.

Awan, S., \& Sheeraz M. (2011). Gender-Oriented Code Switching: A Case-Study of English Language Teachers at Pakistani Universities. 
International Journal of Academic Research 3(4), 410-415.

Draemel, A. F. (2011). Linguistic fusion: A comparative sociolinguistic study of Spanish-English code switching found in natural and planned speech (Master's dessertation). Retrieved from http://lib. dr.iastate.edu/cgi/viewcontent. cgi? article $=3139 \&$ context $=$ etd

Fennema-Bloom, J. R. (2010). CodeScaffolding: A Pedagogic Code Switching Technique for Bilingual Content Instruction. Journal of Education 190(3), 27-35.

Hammink, J. E. (2000). Comparison of the Code Switching Behavior and Knowledge of Adults and Children. Retrieved from http://hamminkj. tripod.com/hamminkCS.pdf

Lipski, J. M. (2005). Code-switching or Borrowing? No sé so no puedo decir, you know. In Selected Proceedings of the Second Workshop on Spanish Sociolinguistics, ed. Lotfi Sayahi and Maurice Westmoreland, 1-15. Somerville, MA: Cascadilla Proceedings Project.

Nilep, C. (2006). Code Switching in Sociocultural Linguistics. Colorado Research in Linguistics 19(1), 1-22. Poplack, S. (1980). Sometimes I'll start a sentence in Spanish Y TERMINO EN ESPAÑOL: Toward a typology of code switching. Linguistics 18(7), 581-618.

Shin, S. (2010). The Functions of Code switching in a Korean Sunday School. Heritage Language Journal 7(1), 91-116.

Wardhaugh, R. (1976). An Introduction to Sociolinguistics. Massachusetts: Cambridge University Press.

Weston, D. (2012). Code switching variation in Gibraltar. International Journal of Bilingualism 17(1), 3-22. 
